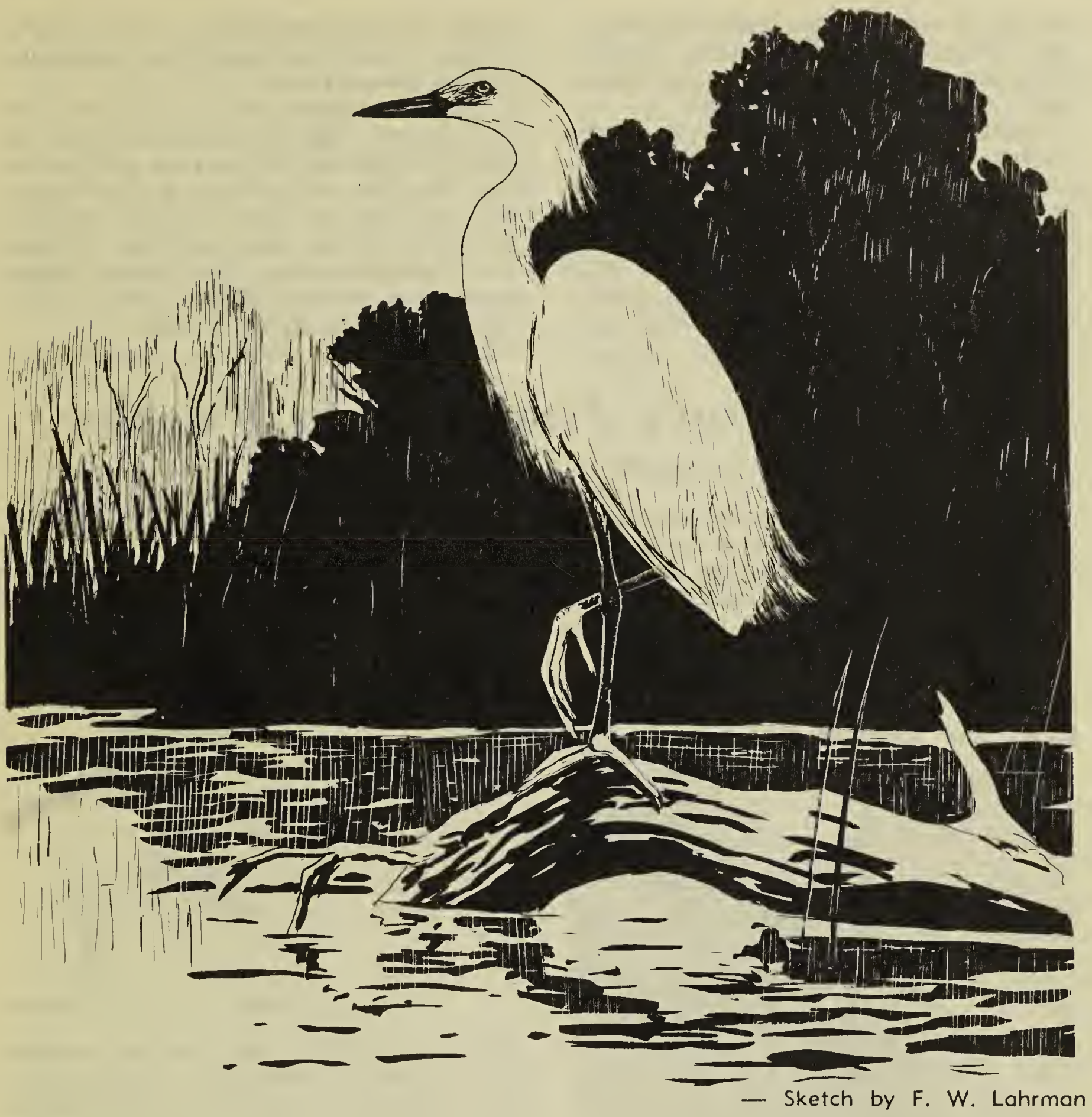

\title{
The Snowy Egret
}

by WILLIAM ANAKA, Spirit Lake, Sask.

Extensive flood conditions prevail in the Spirit Lake district, covering many acres of meadow and cultivated land with shallow sloughs and meandering creeks, creating miles of shoreline which provide excellent feeding grounds for many species of shorebirds and larger waders.

On May 26, Miss Joyce Gunn reported seeing a small white heron in her yard, near the mouth of the creek draining Spirit Lake. I walked out into the nearby flooded meadow and located the bird about one hundred yards away. It flew off on my approach but landed about one quarter mile away, along the creek near a popular bluff. By a long and careful stalk I managed to get behind the bluff and walked to within 25 yards of the bird without being seen. I had an excellent opportunity to observe its markings and habits.

The most outstanding characteristic was its pure white plumage. The long breeding plumes on neck and back were noted. The bill and legs were black. In size and general appearance it resembled a Great Blue Heron scaled down to one third size. It was walking along in shallow water; occasionally it went into a fast shuffle with its feet. Finally spotting me it froze, giving me additional opportunity to check its markings. When it flew off it headed directly away from 
me. As it stretched its legs backwards the yellow feet contrasted sharply with the dark legs, positively identifying it as a Snowy Egret.

Editor's Note: Miss Joyce Gunn writes that this bird was seen for a week (May 23-29) near their buildings. She claims that it was not as much afraid of people as the four birds which came in to feed May 24. These four varied from patchy blue to a very dark blue but they flew at the first sight of man. Miss Gunn is positive that these were the Little Blue Heron.

These reports are confirmed, for the Snowy Egret was also seen in the Qu'Appelle Valley east of Craven. Mr. E. Fox and Mrs. A. Swanston saw its yellow feet clearly on July 9 as it stood on the roadway crossing the flooded valley. The Snowy Egret was seen several times near where the American Egret nests.

\title{
Saskatchewan's First Parula Warbler
}

\author{
By E. MANLEY CALLIN, Fort San, Sask.
}

On May 31, 1956, I was astounded to discover and have a long visit with a male Parula Warbler as it was feeding and singing steadily in a small grove of trees on the grounds of the Fort Qu'Appelle Santorium.

At about 11 a.m. I was walking by the grove and heard an unfamiliar song. The songster was easy to find

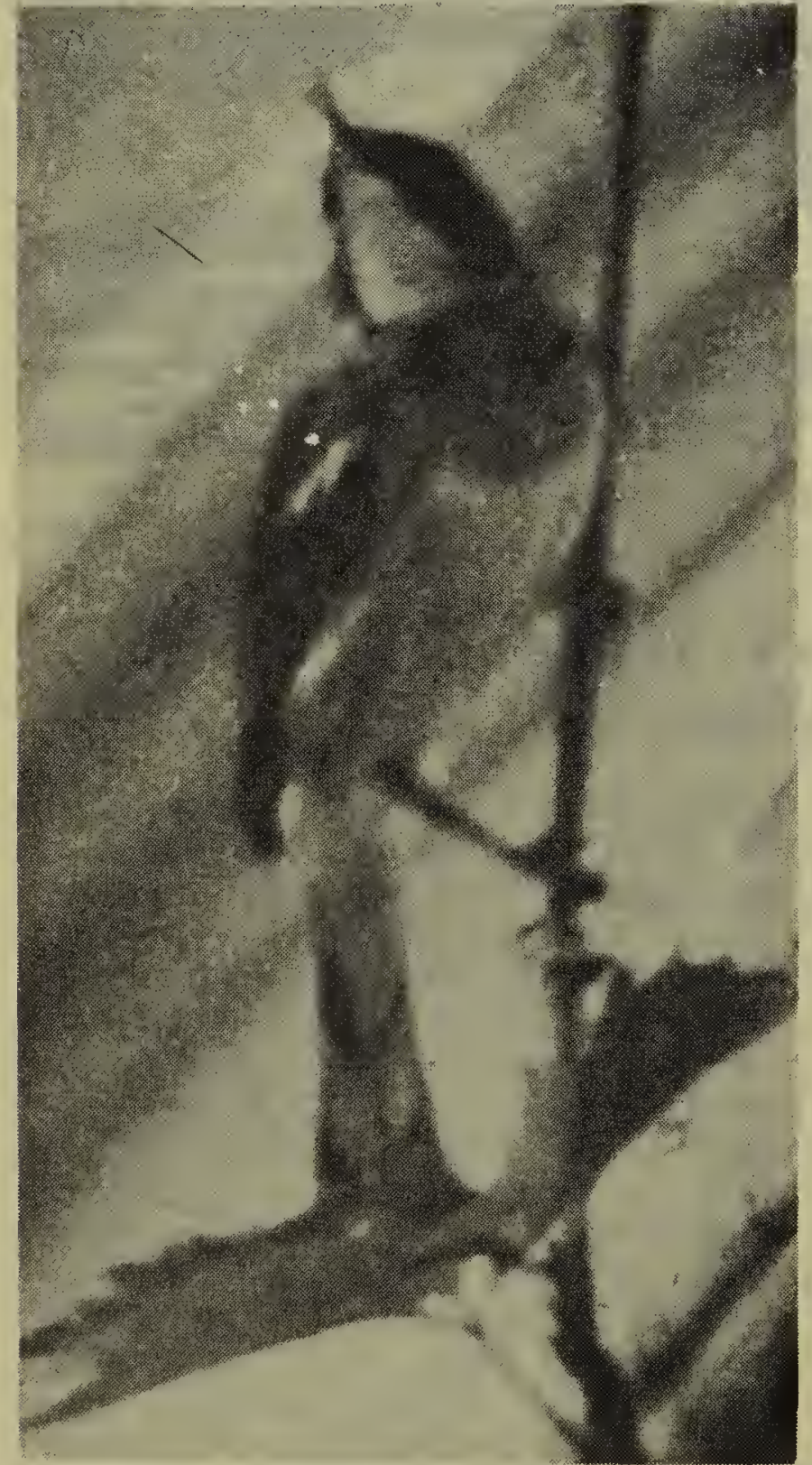

Photo from a Kodachrome by F. W. Lahrman

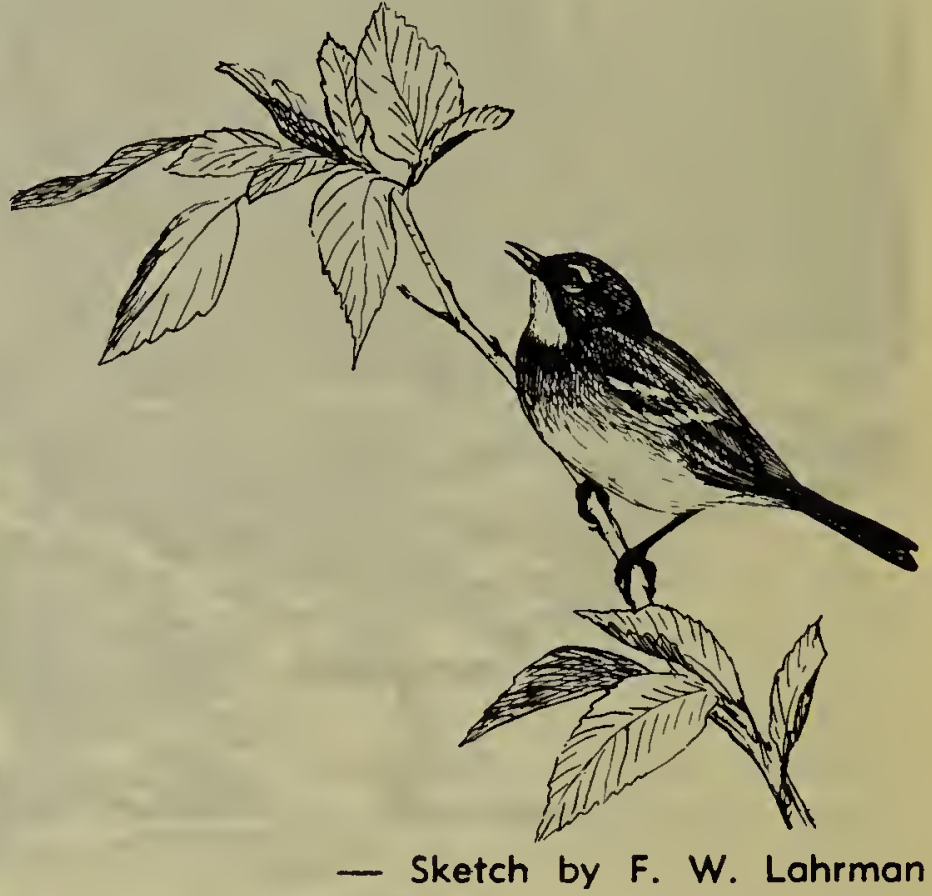

but was moving very briskly among the higher branches of the poplars and conifers, making observation very difficult. Even when it moved to the lower branches it was so active that it took some time to identify the bird. I watched the bird most of the time from 11 a.m. to 1:45 p.m. and it sang and fed steadily, working its way from one end of the grove to the other a number of times. At 1:45 it became silent and disappeared and was not seen or heard again. although I returned three times to listen. I thought that it might have moved on but at 10:30 a.m. on June 1 it was heard again. I, therefore, contacted Mr. Fred Bard, Director of the Provincial Museum at Regina, and he arranged for two of his staff to come out and take a series of color pictures. The bird behaved admirably and a number of pictures verify my identification, a black and white reproduction of one of these is shown below. 